\title{
Putting Workers' Agency at the Centre in the Indonesian Sportswear Industry ${ }^{1}$
}

\section{by Karin Astrid Siegmann, Jeroen Merk and Peter Knorringa}

Globalisation of production has been accompanied by a rise of informal and insecure work across different regions of the world, even in formal establishments. Yet, the role of labour has received scant attention in both the governance and analyses of global production networks (GPNs). Therefore, activists and scholars have demanded a "sea-change in the international business model and the active participation of informed and empowered workers" (Brown 2013: 5) that needs to be flanked by an analytical framework that puts workers' agency at the centre.

This has motivated us to analyse the Freedom of Association Protocol, a voluntary initiative (VI) that has been implemented in the Indonesian sportswear industry since 2011. In that year, Indonesian exports of leather and leather goods peaked, generating more than 230 million USD in revenues (Statistics Indonesia 2014: 107). Overall, more than 600,000 workers were employed in the footwear industry in the same year, including production for the domestic market (CCC 2014). In export factories manufacturing footwear for Nike alone, one of the largest foreign buyers, more than 128,000 workers are currently employed, the vast majority of which are women workers (Nike 2014).

From the perspective of Wright's (2000) theory of the factors enabling positive class compromise, we have asked under which conditions VIs with a more active role for labour can emerge. Wright (2000: 958) defines positive class compromise as "mutual cooperation between opposing classes". It involves concessions in favour of the interests of people in the opposing class. His central argument is that the possibilities for stable, positive class compromise hinge on the relationship between the strength of workers' organisations (i.e., 'associational power') and their ability to help capitalists to solve collective action and coordination problems.

Freedom of association (FoA) and collective bargaining (CB) are often referred to as 'enabling rights', implying that, when these rights are respected, workers can use them to ensure that other labour standards are upheld. While they often formally acknowledge the relevance of FoA and CB, VIs in labour-intensive sectors such as the sportswear industry have a notoriously poor record of implementing and monitoring these collective labour rights. We consider the Indonesian FoA Protocol an far-going structural commitment to strengthening labour. Its study might therefore contain lessons for forms of non-governmental labour regulation that are less far-going in their concessions in favour of labour.

Workers' Struggles in Indonesia and the Emergence of an Alternative Model

All main producer countries for athletic sportswear, namely China and Vietnam alongside Indonesia, have a history of severely curtailed collective labour rights. Both in China and Vietnam, workers are legally restricted to form independent unions. In Indonesia, the Suharto regime (1967-1998) strongly restricted trade union activity and the employee's voice in the workplace. This regularly included army intervention in the case of workers struggles.

These struggles nonetheless had an impact beyond the local and national level when Western media began to cover these events, highlighting sweatshop conditions at famous brands like Nike, Adidas etc. During the 1990s, the contacts between Indonesian labour NGOs and transnational anti-sweatshop networks such as Oxfam Australia, the European-based Clean Clothes Campaigns (CCC), the US-American United Students Against Sweatshop (USAS), the International Textile Garment, Leather Workers Federation (ITGLWF, now IndustriALL) and others became more intense. This international collaboration was continued in the post-Suharto era, e.g. in the Play Fair campaign. Launched in connection with the 2004 Olympic Games held in Athens, this cross-border alliance sought to push sportswear and athletic footwear companies, the International Olympics Committee and its national organising committees, as well as national governments to take concrete measures to address violations of workers' rights in supply chains.

The end of the Suharto regime removed earlier restrictions on trade union establishment, leading to a steep rise in the number of trade unions. Yet, these political and legal changes did not end the violence, intimidation and the imprisonment of outspoken workers or union officials. Despite continued repression, Indonesian trade unions are among the most militant in the region. Therefore, workers' struggles often escalate before even an attempt at finding a resolution can be mounted in the context of existing VIs. The FoA Protocol described below addresses this situation by paving the way to a more effective guarantee of collective labour rights at the firm level.

On June 6, 2011, a protocol on FoA was signed by Indonesian trade unions, large Indonesian sportswear manufacturers and multinational sportswear brands, including Adidas, Nike, Puma, Pentland, New Balance, and Asics. The ratification was one of the results of sportswear campaigns around the 2008 Beijing Olympic Games. The protocol stands out for three reasons: firstly, it led to a process of negotiations around a protocol that provides companies with a set of guidelines on how to uphold and respect trade union rights; secondly, it involved both direct employers and 'indirect' employers, i.e. the brands that that have a powerful role these production networks; and, thirdly, the process was driven by Indonesian union federations instead of being imposed upon them as is most VIs. 
The resulting Protocol establishes practical guidelines for how to ensure that factory workers in Indonesia are able to organise and collectively bargain for better conditions in their workplaces. The agreement also covers areas concerning non-victimisation of trade union officers and members as well as a non-intervention pledge on the part of employers into trade union activities. In addition, the Protocol describes in much more detail than the national law (let alone, multinational brands' VIs) what rights unions can claim at the factory level. This includes, e.g. the right to have an on-site union office, to publicise materials, to access workers etc. Indonesian union representatives find the Protocol to be more detailed than the law, giving more space for workers to organise as a result.

The FoA Protocol: Putting Workers' Agency at the Centre? While it is too early to assess the effectiveness of the FoA Protocol, against the backdrop of union oppression in Indonesia's export industries, its ratification as such is a significant achievement. Yet, it raises the question why capitalists would submit to the unattractive option of structural collaboration with labour through a VI?

Indonesian workers' associational power was enhanced through transnational labour solidarity networks, yet, five diverse local unions were at the forefront of the negotiations for the FoA Protocol. This is reflected in the Protocol's stipulations, which caters to the practical needs of local unions rather than referring to abstract principles. The coordination on the labour side increased pressure on producers and brands who had a less united and clear agenda, but also allowed them to solve their respective collective action problems. This included addressing producers' concerns regarding the choking of production through fierce labour struggles. The Protocol also ensures that defecting producers do not achieve competitive advantage at the expense of collective labour rights. For sportswear brands, the Protocol offers a unique opportunity to protect and increase their reputation as a business community that is 'playing fair' with regards to collective labour rights. Overall, it allows actors in the athletic footwear industry in Indonesia to move from a situation of confrontation to one that has the potential to catalyse cooperation and benefit workers.

Critical question marks are also due. Firstly, we have concentrated on the question which factors have catalyzed the emergence of the FoA Protocol as a VI with the potential to create spaces for workers' collective agency. Yet, the actual impactfor guaranteeing Indonesian sportswear workers' collective rights will be the litmus test for the Protocol's effectiveness. Secondly, we have implicitly defined workers in the Indonesian athletic sportswear industry as those directly employed in manufacturers' plants. A significant number of workers are employed in second tier suppliers, though. Despite trade unions' and their partners' attempts to extend the coverage of the Protocol to second tier producers, these efforts were met with resistance from brands. Hence, even if effective for directly employed workers, one may question whether this VI can be seen as truly contributing to strengthening labour. Thirdly, the sphere of politics may deserve more attention. Which role did the Indonesian political class play in the emergence of the Protocol? While the ratification of the FoA Protocol can be seen as signaling a move towards a greater degree of enforceability of the $\mathrm{VI}$ and inclusiveness regarding the actors involved, we are not yet perceiving a greater commitment of the Indonesian state to enforce legally guaranteed collective labour rights.

Overall, we conclude that while the spatial dispersion of production has weakened state mechanisms for the guarantee of labour rights, new pressure points for labour have also emerged, e.g. brands' reputation or just-in-time production. Besides, new possibilities for transnational labour networks have opened that strengthen workers' associational power. Moreover, GPNs fragment capital in different factions, such as producers and brands. Their material concerns are not necessarily the same. Workers' movements might be able to benefit from such divergent interests, especially if they are in a position to help solving producers and buyers' collective action problems. We conclude that if VIs are to create conditions under which decent work can be strengthened, the involvement and strength of local labour organisations is required and producers' and/or buyers' dependence on workers' cooperation may act as a catalyst.

\section{A longer version of this column has been published as an ISS working paper: http://repub.eur.nl/pub/51297/}

Karin Astrid Siegmann works as a Senior Lecturer in Labour and Gender Economics at the International Institute of Social Studies (ISS) of Erasmus University Rotterdam in The Hague, the Netherlands. Her research is concerned with gendered labour dimensions in global production networks, international migration and financial crises.

Jeroen Merk is David Davies of Llandinam Fellow at the London School of Economics where he works on the project 'Reinventing corporate accountability after the Rana Plaza collapse'.

Peter Knorringa is Professor of Private Sector \& Development at the ISS. His research focuses on how business co-shapes conditions for labour and sustainability.

\section{References}

Brown, G. (2013) 'The Record of Failure and Fatal Flaws of CSR Factory Monitoring', ISHN Journal (February): 1-6.

Clean Clothes Campaign (CCC) (2014) 'Indonesia: Living Wage', draft research on file.

Nike (2014) 'Global Manufacturing'. Available at: http://manufacturingmap.nikeinc.com [accessed April 10, 2014].

Statistics Indonesia (2014) Economic Indicators. Jakarta: Statistics Indonesia.

Wright, E.O. (2000) 'Working-Class Power, Capitalist-Class Interests, and Class Compromise', American Journal of Sociology 105(4): 957 -1002 . 